\title{
Performance evaluation of environmentally compatible stormwater filtration systems
}

\author{
M. P. Samuel · S. Senthilvel • A. C. Mathew
}

Received: 2 September 2011 /Revised: 29 November 2012/Accepted: 18 April 2013/Published online: 25 September 2013

(C) Islamic Azad University (IAU) 2013

\begin{abstract}
A horizontal flow multimedia stormwater filter was developed and tested for hydraulic efficiency and pollutant removal efficiency. Suitability of different natural fibres such as jute, sisal, hemp, coir and oil palm was studied as filter media. Furthermore, the efficacy of different fabric filter screens made up of both woven and nonwoven textiles was also assessed. A new terminology, Universal Performance Index, was introduced. Analysis of these indices showed that jute medium, nonwoven sisal screen and media proportion 1:1:1 performed better. All of the filter combinations exhibited $100 \%$ sediment removal at lower sediment concentration in the inflow. Percentage of discarded flow versus reference flow for the stormwater filter combinations showed that the device performed better at lower flow rates. It was also observed that the hydraulic efficiency was directly proportional to the slope and inversely proportional to the cross-sectional area of the filter. Hydraulic efficiency showed a diminishing trend as the sediment level in inflow increases. By using matrix ranking method, the gravel-coir fibre-sand filter in 1:1:1 proportion with woven sisal hemp screens was selected as the best filter combination. The field evaluation of the filter showed $97.24 \%$ efficiency in normalizing $\mathrm{pH}$ and $13.27 \%$
\end{abstract}

M. P. Samuel ( $\square)$

National Academy of Agricultural Research Management, Hyderabad 500 030, India

e-mail: manojpsamuel@gmail.com

\section{S. Senthilvel}

Department of Soil and Water Conservation, Tamil Nadu

Agricultural University, Coimbatore 641 003, India

A. C. Mathew

Central Plantation Crops Research Institute (ICAR),

Kasaragod 671 124, Kerala, India efficiency in reducing electrical conductivity. The removal percentages of magnesium and sodium were 32 and $34 \%$, respectively. But higher removal efficiencies above $70 \%$ were recorded for total solids, nitrates and sulphates.

Keywords Filter - Stormwater - Fibre - Fabric . Pollutant · Water quality · Hydraulic efficiency

\section{Introduction}

Rainwater harvesting has become the order of the day for ensuring agricultural productivity and domestic as well as industrial water needs. Though rainwater harvesting helps to stabilize the supply-demand equilibrium for water, the quality of water as required for the multi-facets of the water usage arena consistently undergoes validity criteria for a fearless consumption. The qualitative assessment of the water supplies at different stages inevitably would require a multi-stage and fool-proof embedding of effective filtration systems as part and parcel of all rainwater harvesting systems. It is inevitable to establish a filtration mechanism with every rainwater harvesting system, whether it collects direct rainwater, roof water or surface runoff, for removing the debris and contaminants before it enters the harvesting tank (Samuel and Satapathy 2008).

The major reasons of contamination of runoff from agricultural or watershed areas are soil erosion, nutrient leaching, pathogen transport, pesticide leaching and heavy metal accumulation in soil. In agricultural areas, rainwater could have a higher concentration of chemicals due to fertilizer and pesticide residues in the atmosphere, soil and/ or crops. In industrial areas, rainwater samples can have slightly higher values of suspended solids concentration and turbidity due to the greater amount of particulate 
matter in the air (Thomas and Grenne 1993; Chang et al. 2012). When rainwater comes in contact with a catchment surface, it can wash bacteria, moulds, algae, faecal matter, other organic matter and/or dust into storage tanks.

Widespread recognition of negative impacts of urban stormwater (Hatt et al. 2004) has resulted in identification of two important related goals for its management, that is, maintaining stormwater quantity (flood peak and total volume) and quality (pollution) as close to desired levels as possible. A range of stormwater treatment technologies have been developed in response, such as stormwater wetlands, sedimentation ponds, sand filters, infiltration systems and, more recently, bio-filtration systems (Davis 2005; Wong et al. 2006). But most of the available technologies are often found to be unsuitable for applications in developing countries because of the high capital and operating costs involved, regular energy requirements and ill-matched local skills (Bahgat et al. 1999).

It is recommended that rainwater be filtered before entry into the storage tank in order to remove debris such as leaves, grit, moss and soil and dissolved chemicals. Filters should be easy to clean (or self-cleansing) and should not block easily (Martinson and Thomas 2003). Storm water filtration systems with gravel-, sand- or soil-based filter media reduced peak runoff rates and volumes, and retained pollutants prior to discharge to groundwater or receiving surface waters (Hipp et al. 2006). Kim et al. (2006a) tried novel treatment options including lignocellulose filter media and metal membranes and found that the fibre filter media was useful to control first flush rainwater but was not enough to produce water for nonpotable use in buildings. Min et al. (2007) investigated the viability of base-treated juniper fibre (BTJF) media for removing toxic heavy metals $\left(\mathrm{Cd}^{2+}, \mathrm{Cu}^{2+}, \mathrm{Pb}^{2+}, \mathrm{Zn}^{2+}\right)$ in stormwater runoff and found that the sorption ability of the BTJF for all metals was much higher. Hatt et al. (2008) conducted an assessment of the hydraulic and pollutant removal behaviour of sand- and soil-based stormwater filters at the laboratory scale. The influence of time, cumulative inflow sediment, cumulative water volume, wetting and drying, and compaction on hydraulic capacity was investigated. The results suggested that the primary cause of hydraulic failure was the formation of a clogging layer at the filter surface. The use of tertiary membrane-filtered municipal wastewater for irrigation as an alternative to natural freshwater sources was evaluated by Lonigro et al. (2006) in Italy and found that it can be considered a valid alternative source of water for vegetable crop irrigation. In another study conducted in Australia (Johir et al. 2009), a high-rate fibre filter was used as a pre-treatment to stormwater in conjunction with in-line flocculation. Gironas et al. (2008) conducted study of a mixed porous media composed of expanded perlite and a nonwoven needle-punched geotextile to reduce the suspended solids load and concentration in urban runoff. Praveen et al. (2008) studied on coir geotextile-packed conduits for the removal of biodegradable matter from wastewater and found that it could be an acceptable solution for most of the small-scale wastewater treatment units. Kim et al. (2006b) developed a lignocellulose fibre filter media to control heavy metals and nutrients in urban stormwater runoff and found that it was effective in treating stromwater with minimal cost and high efficiency.

However, it is observed that no hydraulically efficient, environmentally compatible and cost-effective filtration mechanisms adoptable to thickly populated urban areas and resource-poor rural areas have been thus far developed in tandem with quality enrichment of stormwater. In this context, a multimedia stormwater filter using biodegradable, environmental friendly and cost-effective filter media such as natural fibres separated by fabric screens was designed, laboratory tested and evaluated in the field. Laboratory studies were carried out at Soil and Water Conservation Engineering laboratory of Tamil Nadu Agricultural University (TNAU), Coimbatore, Tamil Nadu, India, during June-August 2010, and subsequently, field studies were conducted during October-November 2010 at Central Plantation Crops Research Institute (CPCRI), Kasaragod, India, which lies at $76^{\circ} 94$ east longitude $11^{\circ}$ north latitude.

\section{Materials and methods}

\section{Quality parameters of inlet water}

The quality parameters of stormwater from the study sites were analysed for various physicochemical parameters. Input water samples were collected in pre-cleaned polythene bottles with necessary precautions as per standard procedures (IS 3025 1987). The water samples were further analysed for parameters such as $\mathrm{pH}$, electrical conductivity (EC), total dissolved solids (TDS), total solids (TS), total hardness $(\mathrm{TH})$, total alkalinity (TA), calcium $\left(\mathrm{Ca}^{2+}\right)$, magnesium $\left(\mathrm{Mg}^{2+}\right)$, sodium $\left(\mathrm{Na}^{+}\right)$, potassium $\left(\mathrm{K}^{+}\right)$, phosphate $\left(\mathrm{PO}_{4}{ }^{2-}\right)$, sulphate $\left(\mathrm{SO}_{4}{ }^{2-}\right)$, iron $\left(\mathrm{Fe}^{2+}\right)$, chloride $\left(\mathrm{Cl}^{-}\right)$and nitrate $\left(\mathrm{NO}_{3}{ }^{-}\right)$using standard methods and quality assurance procedures. Other three parameters that are useful in evaluating irrigation water quality such as sodium absorption ratio (SAR), residual sodium carbonate (RSC) $\left(\right.$ meq $\left.\mathrm{L}^{-1}\right)$ and exchangeable sodium percentage (ESP) were also computed. The mean of the parameter values obtained by analysing the collected stormwater samples and the corresponding values reported by a few studies conducted within the country (Sinha et al. 2009; $\mathrm{Naz}$ et al. 2009; Karunakaran et al. 2009) are given in Table 1. 
Table 1 Characteristics of storm water

\begin{tabular}{llll}
\hline Sl. no. & Parameters & $\begin{array}{l}\text { Observed data } \\
\text { (mean values) }\end{array}$ & $\begin{array}{l}\text { Secondary data* } \\
\text { (mean values) }\end{array}$ \\
\hline 1 & $\mathrm{pH}$ & 7.1 & 7.6475 \\
2 & $\mathrm{EC}\left(\mathrm{dS} \mathrm{m}^{-1}\right)$ & 1.358 & 2.851 \\
3 & $\mathrm{TS}\left(\mathrm{g} \mathrm{L}^{-1}\right)$ & 8.0545 & 2.568 \\
4 & $\mathrm{TH}$ & 1,305 & 757 \\
5 & $\mathrm{Na}^{+}\left(\mathrm{mg} \mathrm{L}^{-1}\right)$ & 215.7 & 523 \\
6 & $\mathrm{~K}^{+}\left(\mathrm{mg} \mathrm{L}^{-1}\right)$ & 22.4 & 110.3 \\
7 & $\mathrm{Ca}^{2+}\left(\mathrm{mg} \mathrm{L}^{-1}\right)$ & 193.62 & 237.5 \\
8 & $\mathrm{Mg}^{2+}\left(\mathrm{mg} \mathrm{L}^{-1}\right)$ & 51.64 & 342 \\
9 & $\mathrm{NO}_{3}{ }^{-1}\left(\mathrm{mg} \mathrm{L}^{-1}\right)$ & 120 & 110.5 \\
10 & $\mathrm{SO}_{4}{ }^{-}\left(\mathrm{mg} \mathrm{L}^{-1}\right)$ & 390 & 320 \\
11 & $\mathrm{Cl}^{-}\left(\mathrm{mg} \mathrm{L}^{-1}\right)$ & 915 & 777.3 \\
12 & $\mathrm{Fe}^{2+}\left(\mathrm{mg} \mathrm{L}^{-1}\right)$ & 0.1 & 0.98 \\
\hline
\end{tabular}

Preparation of semi-synthetic water

Semi-synthetic stormwater, containing sediment and pollutant load with characteristics typical of urban stormwater (Hsieh and Davis 2005; Hatt et al. 2006), was prepared in a $100-\mathrm{L}$ tank by adding sieved silt $(300-\mu \mathrm{m}$ sieve), sand and fertilizers (urea, $\mathrm{K}_{2} \mathrm{O}$ and $\mathrm{P}_{2} \mathrm{O}_{5}$ ) in limited quantity to the well water. The concentration of chemical parameters in the dosed water was kept equal to the mean of corresponding observed values of physicochemical parameters in storm runoff and that in a simulated runoff from a highly fertilizer- and pesticide-applied area. This dosed water was used for further filtration studies. These large dosing volumes are an exaggeration of real conditions; however, in effect, they provide an assessment of performance under "near worst case" conditions (Hatt et al. 2008).

\section{Design and sizing of filter}

A three-chamber horizontal flow sequential multi-media stormwater filter was designed ("Appendix") with $1.5 \mathrm{~m}$ length, $0.6 \mathrm{~m}$ width and $0.9 \mathrm{~m}$ depth, and subsequently, a dimensionally similitude model was fabricated. The fabricated laboratory model was used for laboratory studies on hydraulic efficiency and quality improvement efficiencies with various media, screens, media proportions and their combinations.

\section{Design and fabrication of laboratory model}

A laboratory model of the stormwater filter was fabricated, which had dimensional similitude with the designed stormwater filter. The internal dimensions of length, width and height of the model were 75,30 and $45 \mathrm{~cm}$, respectively, which were in 2:1 ratio with the field filter. Three filtration chambers with adjustable sizes could be created

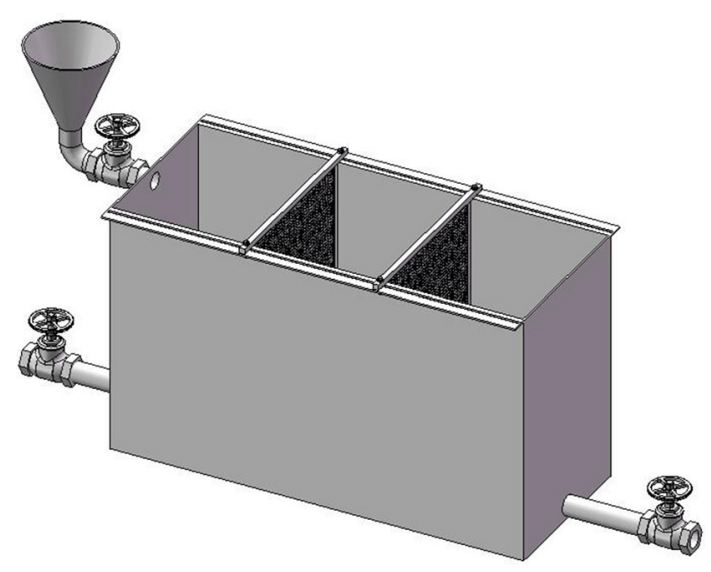

Fig. 1 Stormwater sequential filter with adjustable chambers

(Fig. 1) with the help of movable screens that were bolted on a slotted rail.

The filter was fabricated with 2-mm-thick galvanized iron (GI) sheets. The screens having 2-mm-diameter perforations were made up of 1.5 -mm-thick GI-perforated sheet fixed on a 3-mm angular iron border. Screens served as a separation mechanism between various filter media by avoiding its mixing up and it also helped to retain bigger particles and physical impurities in the flowing water. Provisions were given for attaching textile screens in between the filter chambers replacing metal screen. Three gate valves were fitted at the inlet, outlet and backwash assembly to control the flow of water. There were provisions to measure and collect inlet and outlet water. A provision for changing the slope of the filter bed was also incorporated. The flow of water though the filter was essentially longitudinal in direction though it moves transversely along the filter depth and finally comes out through the exit pipe. There were provisions for pouring dozed water by means of a funnel and back washing the filter at fixed intervals. 


\section{Selection of filter media}

Three filter media were selected for filling up three chambers in the multimedia filtration device. Gravel, which is a course media (mean particle size is $20 \mathrm{~mm}$ ) was selected as the permanent medium to be filled in the first compartment. It acts as a gross particle collector, and sedimentation is the main particle removal process (Ahn et al. 2007). Similarly, sand with mean particle size of $0.7 \mathrm{~mm}$ and uniformity coefficient of 1.46 was fixed as the filter medium for the last compartment, where finer contaminants will be separated by solid-liquid phase separation process. Sorption studies were conducted to finalize the adsorbents to be used in the middle compartment of the filtration device.

The materials used for the sorption study were six types of natural fibres such as sisal (Agave americana), coir (Cocos nucifera), jute (Corchorus capsularis), hemp (Cannabis sativa), banana (Musa paradisiaca) and oil palm (Elaeis guineensis Jacq). All the materials were oven-dried at $80{ }^{\circ} \mathrm{C}$ for $24 \mathrm{~h}$ before use and were stored in polythene bags until further use. The adsorption potential of each fibre material was found out by examining the solute concentration before and after adsorption and time of adsorption was obtained by a series of batch and column experiments.
Selection of screens

Eight different types of screens, which include one metal screen, three woven and four nonwoven needle-punched textile screens, were also tested as a separation cum screening mechanism between layers of filter media. The woven fabric screens selected for the study were sisal $(100 \%)$ (WS), sisal-jute (50:50) (WSJ) and sisal-hemp (50:50) (WSH), while the nonwoven fabric screens tested were sisal (100\%) (NWS), sisal-jute (50:50) (NWSJ), sisal-hemp (50:50) (NWSH) and sisal-coir (50:50) (NWSC).

\section{Experimental setup and design}

An experimental setup consisting of the filter device, an electric pump set that can pump slurry/sediment water, water sump and manometers was arranged, and a total of 90 trial runs were carried out for various filter combinations. The line sketch of experimental setup is depicted in Fig. 2.

Experiment was carried out in completely randomized factorial design (factorial CRD), and each treatment was performed in triplicate. The factors and levels are depicted in Table 2. Difference between treatment means was tested for significance using standard analysis of variance

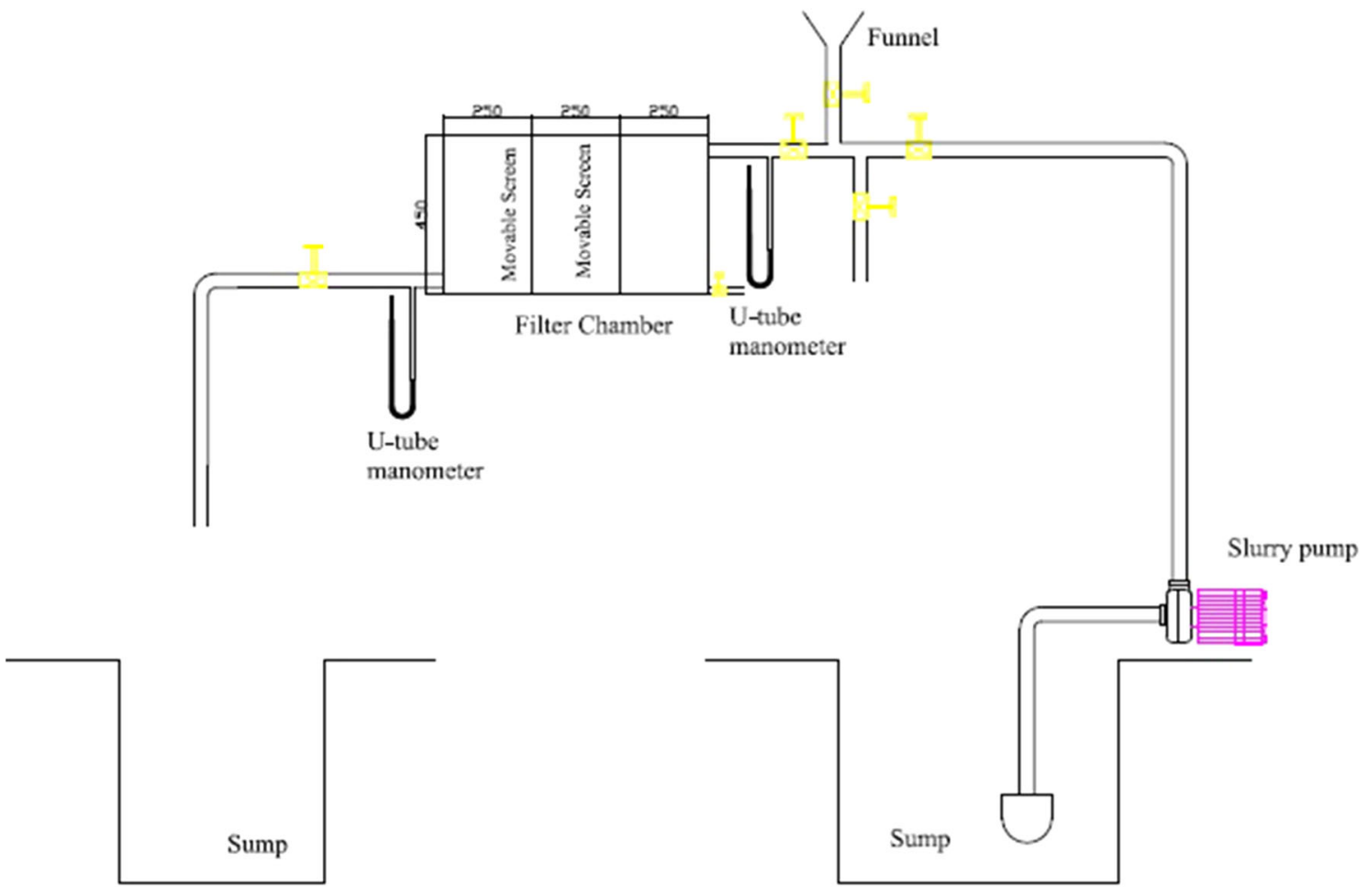

Fig. 2 Experimental setup for stromwater sequential filter 
Table 2 Factors and levels of experiments conducted

\begin{tabular}{lll}
\hline Filter media & Screens & Proportions \\
\hline Gravel-charcoal-sand (GCS) (M1) & Woven sisal (WS) (S1) & $1: 1: 1$ (P1) \\
Gravel-fibre (sisal)-sand (GFsS) (M2) & Woven sisal jute (WSJ) (S2) & $1: 2: 3$ (P2) \\
Gravel-fibre (jute)-sand (GFjS) (M3) & Woven sisal hemp (WSH) (S3) \\
Gravel-fibre (oil palm)-sand (GFopS) (M4) & Nonwoven sisal (NWS) (S4) \\
Gravel-fibre (coir)-sand (GFcS) (M5) & Nonwoven sisal jute (NWSJ) (S5) \\
& Nonwoven sisal hemp (NWSH) (S6) \\
& Nonwoven sisal coir (NWSC) (S7) \\
& Metal screen (MS) (S8) \\
& No screen (S9) \\
\hline
\end{tabular}

(ANOVA) tests. The general linear models (GLM) procedure of statistical analysis system (SAS) was employed in this study. Subsequently, least square difference (LSD) method or Duncan's new multiple range test was employed for multiple comparisons of treatments.

\section{Experimental measurements}

The rate of inflow was measured first by using a measuring cylinder and a stop watch. Once the outflow is stabilized, its rate of flow was measured using same procedure. The inlet pressure and outlet pressures were measured by means of a U-tube manometer. The experiments were first completed with well water and subsequently with semi-synthetic dosed water, both collected in the tank. The filtered water samples were collected as per standard methods in plastic containers and sent for analyses.

The filter was designed in such a way that $0.81 \mathrm{~m}^{3}$ of filter volume can treat $33 \mathrm{~m}^{3}$ of storm water per day $\left(0.81 \mathrm{~L} \mathrm{~s}^{-1}\right)$. Therefore, the laboratory model having a volume of $0.101 \mathrm{~m}^{3}$ can treat $4.115 \mathrm{~m}^{3}$ of water daily, so that the inflow rate should be $0.048 \mathrm{~L} \mathrm{~s}^{-1}$. Hence, the tests were conducted at an inflow rate of $0.05 \mathrm{~L} \mathrm{~s}^{-1}$. A steady outflow at uniform rate was obtained after $30 \mathrm{~s}$ to $6 \mathrm{~min}$ of elapsed time since the inlet water started flowing through the filter depending on the filter screen combinations. Hence, the outlet filtered water was collected after $6 \mathrm{~min}$ from the start of each experiment. The retention time is therefore considerably less $(0.5-6 \mathrm{~min})$ as in case of other continuous flow filters.

\section{Hydraulic efficiency}

Hydraulic efficiency (HE) is the measure of the fraction of the incoming stream that penetrates through the filter (Martinson and Thomas 2003). The rate of inflow and outflow was measured in three replications, and subsequently, the amounts of water penetrated through and spilled over the filter were calculated.

$$
\begin{aligned}
\mathrm{HE}= & \text { rate of outflow } * 100 / \text { rate of inflow } \\
= & \left(Q_{\text {in }} / Q_{\text {out }}\right) * 100 \\
= & (\text { rate of inflow }- \text { rate of spilled over water }) \\
& * 100 / \text { rate of inflow }
\end{aligned}
$$

\section{Filter effectiveness}

The filter effectiveness can be expressed as the fraction of total particulates removed by the filter. For a certain chemical parameter, the average percentage removal was calculated as follows (Hamoda et al. 2004):

$\% R_{\mathrm{a}}=\left[\left(C_{\mathrm{i}}-C_{\mathrm{o}}\right) / C_{\mathrm{i}}\right] 100$

where $R_{\mathrm{a}}=$ average percentage removal of certain chemical parameter; $C=$ concentration of a certain chemical parameter, subscripts "i" and "o" refer to the inlet and outlet water of the filter device, respectively $\left(\mathrm{mg} \mathrm{L}^{-1}\right)$.

The same types of formulae were used for finding out the EC-reducing efficiency and sediment removal efficiency. However, since the $\mathrm{pH}$ has to be brought to the neutral value of 7 by the filtration process, another equation is formulated to find out the $\mathrm{pH}$-normalizing efficiency as given below:

$\mathrm{pH}$ normalizing efficiency $=\left[\frac{\mathrm{pH}_{\mathrm{i}}-\left|7-\mathrm{pH}_{\mathrm{o}}\right|}{\mathrm{pH}_{\mathrm{i}}}\right] 100$

where $\mathrm{pH}_{\mathrm{i}}=$ initial $\mathrm{pH}$ of water before filtration; $\mathrm{pH}_{\mathrm{o}}=\mathrm{pH}$ of water after filtration

The term filter effectiveness is the mean of the $R_{\mathrm{a}}$ values with respect to all analysed physicochemical parameters and the $\mathrm{pH}$-normalizing efficiency and it is identical to the overall quality-improving efficiency (QIE), which is referred in the following text.

\section{Universal Performance Index}

The Universal Performance Index (UPI), a new terminology, was introduced and it is the weighted average of the 
hydraulic efficiency and quality-improving efficiencies, giving extra weightage to the latter. The UPI can be calculated as follows:

$\mathrm{UPI}=\frac{1}{2(n+1)}\left[\mathrm{HE}+2 * \sum_{i=1}^{i=n} \mathrm{QIE}_{i}\right]$

where $\mathrm{HE}=$ hydraulic efficiency, $\quad \mathrm{QIE}_{i}=$ quality improvement efficiency with respect to $i$ th parameter, $n=$ total no of chemical parameters tested

A total of $90(5 \times 9 \times 2)$ experiments were conducted by packing the filter with four types (M2 to M5) of natural fibres such as sisal, jute, oil palm and coir along with gravel and sand, in two proportions (P1 and P2) with eight different types of screens (S1 to S8). Charcoal was kept as the control media (M1) and no screen (S9) as the control screen. The rates of inflow, outflow and the retention time were observed for each of the filter combinations. The influent and effluent water samples were first analysed for its change in quality characteristics such as EC, $\mathrm{pH}$ and TS. Based on the observed data, the hydraulic efficiency and filter effectiveness of each experiment were found out.
Sensitivity of hydraulic efficiency with respect to different media, screens and media proportions was also studied.

Difference between treatment means were tested for significance using ANOVA and the best media, screen and combination with respect to sediment removal efficiency, $\mathrm{pH}$-normalizing efficiency and EC-reducing efficiency, and UPI was delineated based on ranking by comparison of treatments using Duncan's MRT method. Out of the 90 filter combinations tried, the superior 45 filter combinations that exhibited significantly higher performance based on its UPI values were delineated for detailed chemical analyses of water parameters. The remaining filter combinations were discarded due to its low filtration efficiencies. Detailed quality analysis was conducted for 12 parameters, and corresponding chemical removal efficiencies were worked out. Matrix ranking method (Wanielista and Chang 2008) was employed to find out the superior filter combinations among the 45 combinations for which the detailed water analysis were undertaken. Hydraulic performance and filtration efficiency of the selected multimedia filters were studied.
Fig. 3 Filtration tank with sedimentation chamber constructed in field

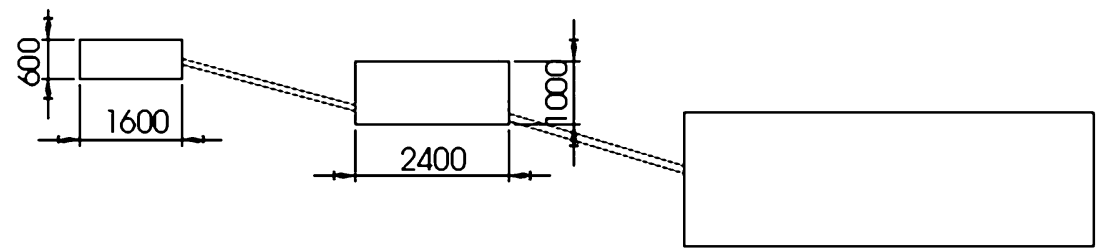

Elevation of field stormwater filter

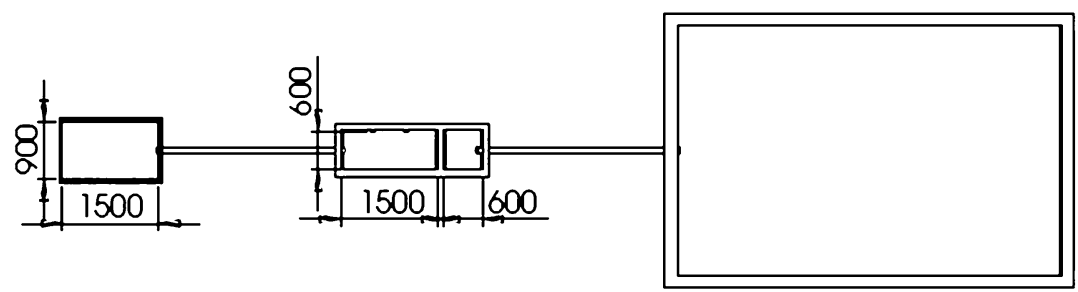

Plan of field stormwater filter

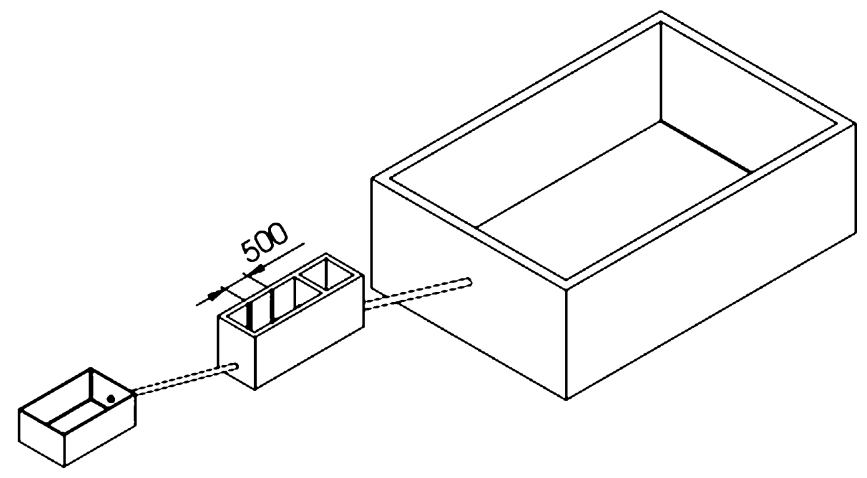


Field evaluation

The filter combination found to be the best in the laboratory experiments was tested and validated in the field. Field testing of the selected filter combination was done at Kasaragod, India. The selected area was located at $\mathrm{msl}$ of $12 \mathrm{~m}$, and the soil was mainly lateritic in nature with around $10-11 \%$ of impervious area. The filter system consisted of a sedimentation chamber with overflow pipes designed to skim off floatable debris and a filter with three chambers separated by screens. Figure 3 shows a perspective of this installation. The filter device was constructed in such a way that the filtered water should reach the harvesting tank through a pipe conduit connected between the two structures.

The filter chambers were filled in such a combination that gravel in first chamber, sand in last chamber and the best selected adsorbent media in the middle chamber. The media were separated by inserting the selected best screen through the grooves provided. The media were filled up to a height of $60 \mathrm{~cm}$, and the remaining $30 \mathrm{~cm}$ was kept as extended detention depth (Fletcher et al. 2004).

The rate of inflow and outflow was measured using a $\mathrm{V}$-notch weir. The height of water in the filter and the extended detention depth (free board) were also noted. Discrete flow samples were taken at the inlet, just upstream of the filter and at the filter's outlet pipe as per standard procedures. All samples were flow-weight composited to obtain accurate event mean concentrations for each storm.

Table 3 Packing densities of fibres

\begin{tabular}{lll}
\hline Sl. no. & Material & Packing density $\left(\mathrm{kg} \mathrm{m}^{-3}\right)$ \\
\hline 1 & Coir & 33 \\
2 & Oil palm & 40.8 \\
3 & Jute & 54.8 \\
4 & Sisal & 41 \\
\hline
\end{tabular}

The filter was designed to operate off-line during larger storms, meaning that flow volumes larger than the design treatment capture volume bypassed the filter itself.

The collected water samples were subjected to detailed analysis as per standard methods for finding out the various physicochemical parameters.

\section{Results and discussion}

Based on the batch study and column study, coir, sisal, jute and oil palm fibres that exhibited high adsorption capacities of $\mathrm{NO}_{3}{ }^{-}$were identified for further laboratory and field trials. The packing densities of the selected fibre media in the filter are given in Table 3.

Relationship between volume of filter media and hydraulic efficiency (HE) was studied at an inflow rate of $0.05 \mathrm{~L} \mathrm{~s}^{-1}$ with $1 \%$ filter gradient (Fig. 4). It was observed that gravel showed greater efficiency of water conductance, obviously because of its high porosity. The coir fibre was found to be having next higher hydraulic efficiency. But the HE values of other fibres such as jute, sisal and oil palm were found to be inferior to those of sand, especially at lower filter volumes. The lower HE can be attributed to the close knitted structure of those fibres. Comparing the hydraulic efficiencies of different fibre media, it can be concluded that jute and coir fibres could be recommended as better filter media.

Similarly, hydraulic conductivity of the selected screens at varying inflow rates is depicted in Fig. 5. Filter screens such as woven sisal, woven sisal jute, woven sisal hemp and metal screen showed better hydraulic conductivity compared to various nonwoven screens. The higher hydraulic conductivity of woven screens is due to its knitted structure with uniform perforations.

Kim et al. (2006a) studied the change in permeability of metal membranes as a function of filtration time and found that the permeability is directly proportional to size of
Fig. 4 Effect of volume of filter media on hydraulic performance




Fig. 5 Effect of inflow on hydraulic conductivity of screens

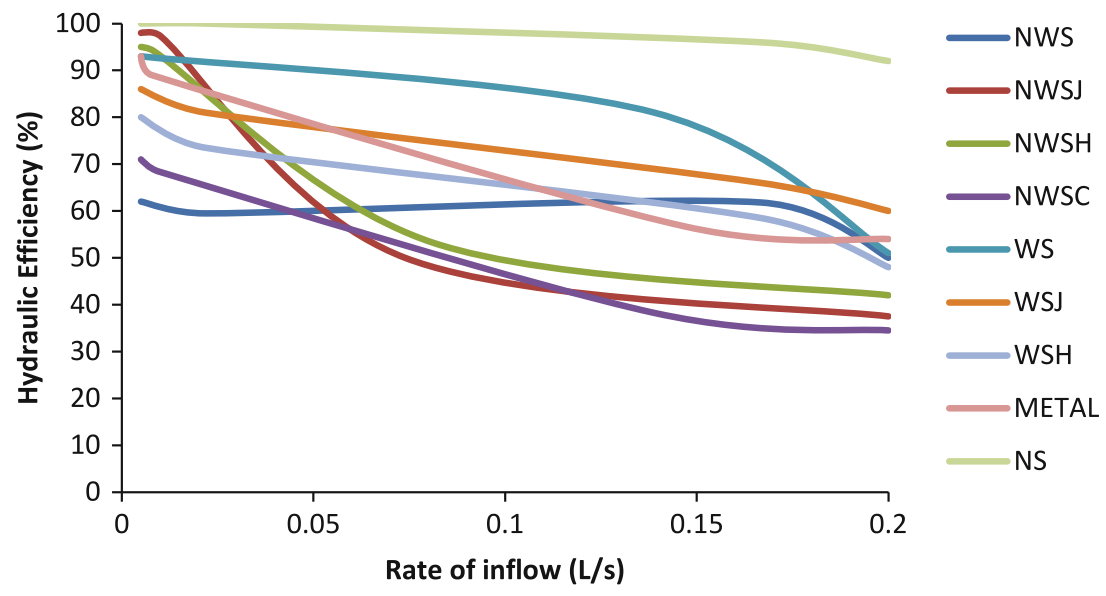

perforations in the filter membranes. Therefore, it can be inferred from the graph that woven sisal (WS) screen is the fabric membrane with biggest pore size as it showed comparatively higher permeability consistently.

\section{Hydraulic efficiency}

Analysis of variance of hydraulic efficiency values with respect to the tested filter combinations at 0.01 significance level showed that all factors and their two-way and threeway interactions were highly significant. The ranked orders of the main effects and their interactions showed that proportion P1 (1:1:1), media M1 (charcoal) and screen S9 (no screen) had emerged as the highest performers, while combination P1M4S9 was found as the filter combination having highest mean value of hydraulic efficiency. Among the fibre media and textile screens, sisal fibre and woven sisal hemp screen were emerged superior.

Sensitivity of hydraulic efficiency for filter screens with the best media and proportion was studied. Only fibre media and fabric screens were considered for the sensitivity analysis as they belong to similar material group. Figure 6 shows the hydraulic performance of various screens in a gravel-sisal fibre-sand multimedia filter filled in 1:1:1 proportion. It is clear from the figure that woven sisal hemp performed better compared to other fabric screens and its hydraulic efficiency was almost at par with metal screen except at very low and high flow rates. Similarly, the behaviour of hydraulic efficiency of different media with respect to the best proportion (1:1:1) and the best screen (woven sisal hemp) is shown in Fig. 7a. Sisal fibre performed well followed by coir fibre and charcoal. Charcoal media showed higher permeability at lower flow rates. Variation in hydraulic efficiency with the change in media proportions keeping the best media (sisal fibre) and screen (woven sisal hemp) is depicted in Fig. 7b. The graph shows higher permeability with respect to $1: 1: 1$ proportion except when flow rates were less than $0.02 \mathrm{~L} \mathrm{~s}^{-1}$. Hatt et al. (2009) reported for a stormwater bio-filter device that the total volume lost was clearly proportional to the inflow volume, with losses increasing with inflow volume. The present study also showed the same trend as the volume lost is inversely proportional to the hydraulic efficiency. Initial reduction in the flow rate across the filter indicates movement of fine particles towards the filter screens, thereby clogging of the screen openings. In most of the cases, subsequent retention of soil particles on the fibre media and fabric screens led to cake formation, resulting in a reduction in flow rate until an equilibrium condition was reached. Bergado et al. (1996) observed the same phenomenon in case of a prefabricated vertical drain geotextile filter jackets in soft Bangkok clay. This has important implications for management of urban waterways, where increased flows are a key stressor (Paul and Meyer 2001).

The reduction in peaks is also particularly important for managing stormwater systems in existing areas that are subject to urban densification. The surface area of the multimedia filter used in the study was only approximately $0.1 \%$ of the impervious catchment area, substantially smaller than the typical $2 \%$ used in practice for bio-filters (Melbourne Water 2005), $1 \%$ for surface sand filters and $<1 \%$ for organic media (Claytor and Schueler 1996). However, hydraulic efficiency of the GFS filter can be further improved by marginally increasing the surface area.

Quality-improving efficiencies

ANOVA was conducted separately for various qualityimproving efficiencies such as sediment removal efficiency, $\mathrm{pH}$-normalizing efficiency and EC-reducing efficiency, and the results of the analyses are given in Table 4. 
Fig. 6 Sensitivity of hydraulic efficiency for different filter screens with the best media and proportion

Fig. 7 Sensitivity of hydraulic efficiency a for different filter media with the best screen and proportion $\mathbf{b}$ for different proportions with the best media and screen
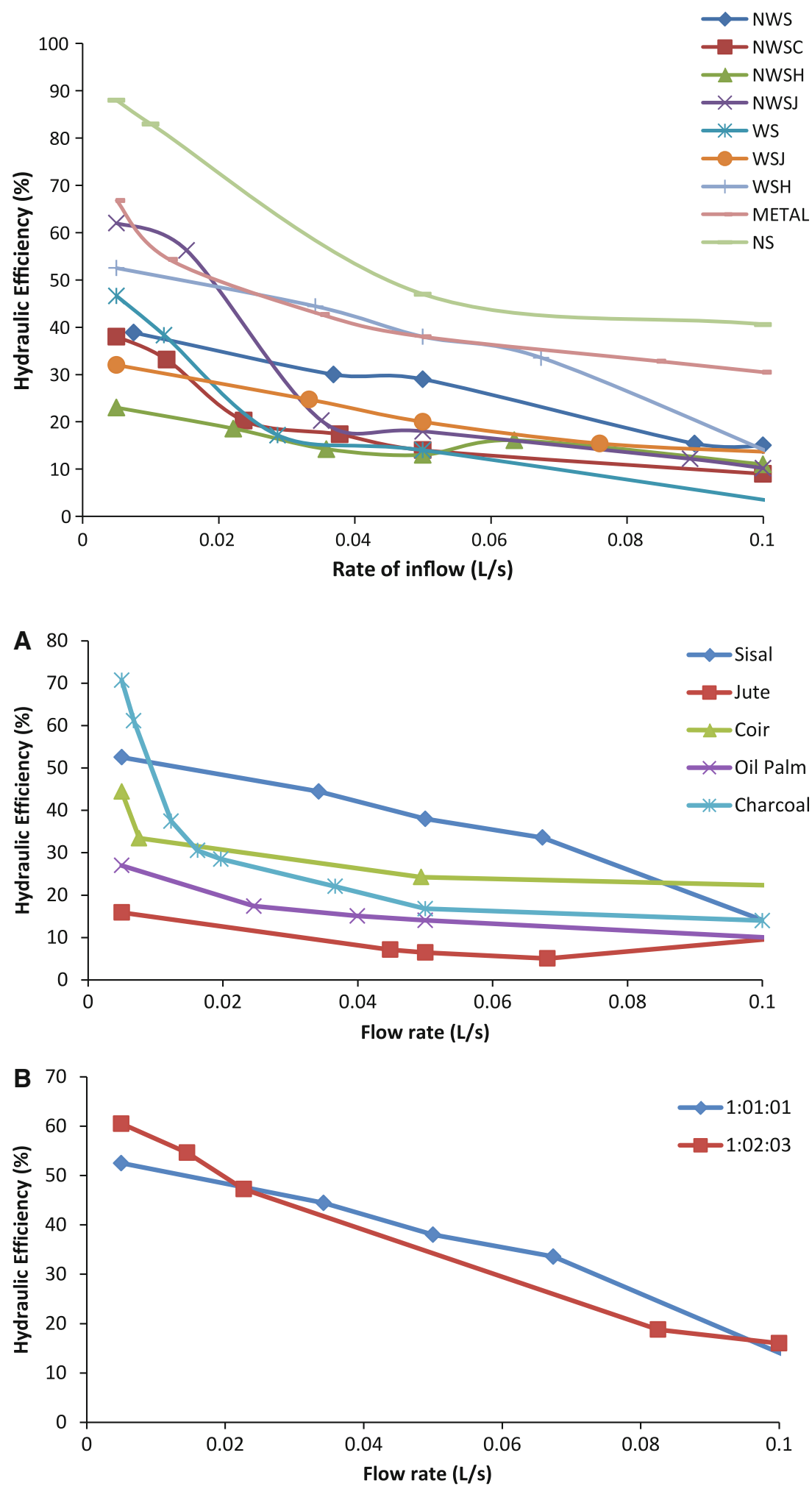

\section{Universal Performance Index}

ANOVA results of UPI showed a significance level of $<1 \%$ among mean values and between combinations. Comparison of the treatments by LSD method showed the media jute (M3), nonwoven sisal (S4) screens and media proportion 1:1:1 (P1) as the best.

The superior 45 filter combinations that exhibited significantly higher performance based on its UPI values were delineated for detailed chemical analyses of water parameters. 
Table 4 ANOVA summary of sediment removal efficiency, pH-normalizing efficiency and EC-reducing efficiency of GFS filter combinations

\begin{tabular}{|c|c|c|c|c|c|c|}
\hline \multirow[t]{2}{*}{ Factor } & \multicolumn{2}{|c|}{ Sediment removal efficiency } & \multicolumn{2}{|c|}{ pH-normalizing efficiency } & \multicolumn{2}{|c|}{ EC-reducing efficiency } \\
\hline & $\begin{array}{l}\text { " } F \text { " value/ } \\
\text { significance }\end{array}$ & $\begin{array}{l}\text { Best rank (Duncan's } \\
\text { MRT) }\end{array}$ & $\begin{array}{l}\text { "F" value/ } \\
\text { significance }\end{array}$ & $\begin{array}{l}\text { Best rank (Duncan's } \\
\text { MRT) }\end{array}$ & $\begin{array}{l}\text { "F" value/ } \\
\text { significance }\end{array}$ & $\begin{array}{l}\text { Best rank (Duncan's } \\
\text { MRT) }\end{array}$ \\
\hline $\mathrm{P}$ & $1,553.202 * *$ & $\mathrm{P} 1$ & $0.20^{\mathrm{NS}}$ & $\mathrm{P} 2$ & $75.22 * *$ & $\mathrm{P} 1$ \\
\hline M & $1,893.888 * *$ & M3 & $2.59 *$ & M4 & $44.83 * *$ & M1 \\
\hline $\mathrm{S}$ & $3,740.724 * *$ & S7 & $3.30 * *$ & S4 & $28.31 * *$ & S8 \\
\hline PM & $664.688 * *$ & P1M3 & $0.2^{\mathrm{NS}}$ & $\mathrm{P} 2 \mathrm{M} 4$ & $8.53 * *$ & P2M1 \\
\hline MS & $90.13 * *$ & M3S2 & $1.29^{\mathrm{NS}}$ & M4S7 & $4.04 * *$ & $\mathrm{M} 2 \mathrm{~S} 8$ \\
\hline PS & $1,193.958 * *$ & P1S7 & $3.22 * *$ & P1S4 & $50.34 * *$ & P1S8 \\
\hline PMS & $1,298.69 * *$ & P1M5S1 & $1.14^{\mathrm{NS}}$ & P1M4S7 & $4.17 * *$ & P1M2S8 \\
\hline
\end{tabular}

NS nonsignificant

* Significant at $5 \%$ level; ** significant at $1 \%$ level

Effect of filter combinations on chemical removal

Average percentage removal of major physicochemical constituents from water by fibre-filled filters is shown in Table 5. The average removal efficiency of eight chemical parameters and TS for the tested filter combinations was $30.81 \%$.

The $\mathrm{pH}$ of the samples tends to become neutral after filtration. Alkalinity was reduced most likely by the adsorbent layer in the filter comprising either charcoal or fibre. Average $\mathrm{pH}$-normalizing efficiency obtained was $92.62 \%$. The observed average EC-reducing efficiency was $13.7 \%$. This shows that the number of ions present in the stormwater sample reduced after the filtration process. Kim et al. (2006a) reported that by using $1-\mu \mathrm{m}$ metal membrane filter, the EC of a mixture of grey water and rainwater could be brought down from 0.1562 to $0.1399 \mathrm{dS} \mathrm{m}^{-1}$ (10.4\% removal efficiency).

Total solid concentration is the sum of both the particulate and dissolved solids content in the water samples. The average reduction in total solid load was $83.2 \%$. However, $45 \%$ of filter combinations showed $100 \%$ reduction. Most likely this could be due to sand and fibre layers that are capable of removing fine particles from water. The total dissolved solids (TDS) contributed more than $50 \%$ of the TS in the influent. The removal efficiency of TDS was found to be $67.82 \%$. Though the average removal efficiency of total suspended solids (TSS) was $98.45 \%$, it was observed that $89 \%$ of the filter combinations showed $100 \%$ removal of suspended particles. The removal percentage of TSS in the present study was in concurrence with the study results by Johir et al. (2009), who reported a removal percentage of $94-98$ for suspended solids by using a fibre filter.

The average percentage removal values of sodium, calcium and magnesium were $23.98,3.34$ and 35.5 , respectively. The maximum removal values recorded were as high as $56.96 \%$ for $\mathrm{Na}$ and $42 \%$ for $\mathrm{Mg}$. The minimum values were found negative for $\mathrm{Na}$ and $\mathrm{Ca}$, which implies an increase in concentration of the particular chemicals after filtration, and the reason for this could be attributed to the preferential leaching of cations from organic matter. But it was observed that for all filter combinations, the potassium $(\mathrm{K})$ content got increased after filtration $(-10.27 \%$ average removal efficiency). This would probably be due to preferential leaching effects from bio-fibres with high soluble $\mathrm{K}$ content. By this process, a portion of chemically active ions might get dissolved into the water when it flows through the fibre media and screens.

Table 5 Parameter-wise removal efficiencies

\begin{tabular}{|c|c|c|c|c|c|c|c|c|c|c|c|}
\hline Parameters & $\mathrm{pH}$ & $\mathrm{EC}^{1}$ & $\mathrm{TS}$ & $\mathrm{Ca}^{2+}$ & $\mathrm{Mg}^{2+}$ & $\mathrm{Na}^{+}$ & $\mathrm{NO}_{3}{ }^{-}$ & $\mathrm{Cl}^{-}$ & $\mathrm{SO}_{4}^{2-}$ & TA & $\mathrm{TH}$ \\
\hline Average removal efficiency $(\%)$ & 92.62 & 13.73 & 83.20 & 3.34 & 35.58 & 23.98 & 38.48 & 17.37 & 46.59 & 10.91 & 15.05 \\
\hline SD & 3.92 & 5.02 & 17.84 & 3.65 & 2.45 & 21.25 & 21.30 & 6.05 & 10.24 & 7.27 & 6.48 \\
\hline \multicolumn{12}{|l|}{ Range } \\
\hline Min & 85.66 & 4.81 & 50 & -3.29 & 30.65 & -29.68 & -15.56 & 8.42 & 23.48 & 0 & 8 \\
\hline Max & 99.74 & 35.58 & 100 & 12.87 & 42 & 56.96 & 79 & 42.11 & 81.74 & 45.88 & 45.88 \\
\hline
\end{tabular}


The average values of sodium absorption ratio (SAR), residual sodium carbonate (RSC) (meq $\mathrm{L}^{-1}$ ) and exchangeable sodium percentage (ESP) were also calculated. The mean SAR, RSC and ESP values were 5.76, -0.085 and 52.26 , respectively, which are with in safe limits for irrigation.

The average $\mathrm{NO}_{3}{ }^{-}$removal was $38.48 \%$. Egan et al. (1995) reported $75 \%$ nitrate removal in case of a packed gravel bed filter system in Florida, USA. The removal of organic forms of nitrogen in most gravel filters was generally high, ranging from 60 to $75 \%$. Johir et al. (2009) reported a nitrate reduction in stormwater using a fibre filter media from the range $0.38-0.79$ to $0.005-0.093$ $\mathrm{mg} \mathrm{L}^{-1}$ (approximately $93 \%$ reduction). However, denitrification process was the major removal mechanism in all these cases. But as per Hsieh and Davis (2005), bioretention method was less effective for nitrate removal $(<20 \%)$. The comparatively less removal efficiency in the present study could be attributed to the leaching of nitrate salts from organic materials, such as fibres/charcoal used as filter media, absence of denitrification process and/or less residence time of stormwater in the filter. It is inferred that major portion of nitrate had been removed by the process of adsorption rather than nitrification/denitrification process.

The average sulphate removal percentage $(46.59 \%)$ was the highest among the removal efficiencies of all chemicals. Similar pattern of sulphate reduction was reported by
Wildeman et al. (1997). The average removal efficiency of chloride was found around $17 \%$. Phosphate concentration in the influent water was so low, and with such a low influent concentration, it was not expected that substantial removals would be seen.

Presence of calcium and magnesium salts in the stormwater was the major reason for Hardness. Filtration process in the present study could reduce the total hardness by $15 \%$. Meanwhile, the total alkalinity was reduced by $11 \%$. Yuzwa and Eng (1982) reported a 5-10 \% reduction in raw water alkalinity by using a brine and caustic regeneration system.

It could be concluded from the present study that the multi-media filter system (sand, gravel and fibre) separated by fabric screens was excellent in removing sediments, and fairly good in reducing sulphate, nitrate, magnesium and sodium concentrations. It performed comparatively poor in removing chloride and calcium and reducing the total hardness and alkalinity.

\section{Selection of superior filter combinations}

Matrix ranking method was employed to find out the superior filter combinations among the 45 combinations for which the detailed water analysis were undertaken. All of the removal efficiencies were equally weighted, and the qualitative assessment was then converted to a numerical

Table 6 Matrix ranking of best filter combinations based on chemical removal efficiencies

\begin{tabular}{|c|c|c|c|c|c|c|c|c|c|c|c|c|c|c|c|}
\hline $\begin{array}{l}\text { Sl. } \\
\text { no. }\end{array}$ & $\begin{array}{l}\text { Filter } \\
\text { code }\end{array}$ & Details & $\mathrm{pH}$ & EC & TS & $\mathrm{Ca}^{2+}$ & $\mathrm{Mg}^{2+}$ & $\mathrm{Na}^{+}$ & $\mathrm{NO}_{3}{ }^{-}$ & $\mathrm{Cl}^{-}$ & $\mathrm{SO}_{4}{ }^{2-}$ & TA & TH & $\begin{array}{l}\text { Total } \\
\text { score }\end{array}$ & $\overline{\text { Rank }}$ \\
\hline 1 & P1M1S8 & Charcoal-metal screen (1:1:1) & & & & 1 & 5 & & & 5 & & & 1 & 12 & IV \\
\hline 2 & P1M5S3 & $\begin{array}{l}\text { Coir fibre-woven sisal hemp } \\
\text { screen }(1: 1: 1)\end{array}$ & 5 & & 5 & 5 & 3 & & & & & 5 & 5 & 28 & I \\
\hline 3 & P1M3S3 & $\begin{array}{l}\text { Jute fibre-woven sisal hemp } \\
\text { screen }(1: 1: 1)\end{array}$ & 3 & & 5 & 3 & 1 & & & & & & 3 & 15 & III \\
\hline 4 & P1M5S1 & $\begin{array}{l}\text { Coir fibre-woven sisal screen } \\
(1: 1: 1)\end{array}$ & & 5 & 5 & & & & & & & & & 10 & $\mathrm{~V}$ \\
\hline 5 & P1M3S6 & $\begin{array}{l}\text { Jute fibre-nonwoven sisal hemp } \\
\text { screen }(1: 1: 1)\end{array}$ & & & 5 & & & & & & 3 & & & 8 & \\
\hline 6 & $\mathrm{P} 2 \mathrm{M} 2 \mathrm{~S} 3$ & $\begin{array}{l}\text { Sisal fibre-woven sisal hemp } \\
\text { screen }(1: 2: 3)\end{array}$ & & & 5 & & & & 1 & & & & & 6 & \\
\hline 7 & P1M5S6 & $\begin{array}{l}\text { Coir fibre-nonwoven sisal hemp } \\
\text { screen }(1: 1: 1)\end{array}$ & & & 5 & & & & & & & & & 5 & \\
\hline 8 & P2M3S2 & $\begin{array}{l}\text { Jute fibre-woven sisal jute screen } \\
(1: 2: 3)\end{array}$ & & & 5 & & & & & & & 1 & & 6 & \\
\hline 9 & P1M2S6 & $\begin{array}{l}\text { Sisal fibre-nonwoven sisal hemp } \\
\text { screen }(1: 1: 1)\end{array}$ & & & 5 & & & 5 & 5 & & 5 & & & 20 & II \\
\hline 10 & P1M4S4 & $\begin{array}{l}\text { Oil palm fibre-nonwoven sisal } \\
\text { screen }(1: 1: 1)\end{array}$ & & & 5 & & & & & & & & & 5 & \\
\hline
\end{tabular}


value by giving scores to the filter combinations as per its ranking (Wanielista and Chang 2008). Ten filter combinations that performed better in removing the chemical impurities were selected for matrix ranking analysis. For each chemical parameter, the rank I combination was given a score of 5 , rank II was given 3, and rank III combination was assigned a score of 1 ; finally, the filter combinations were ranked based on the total score obtained (Table 6).

Based on the matrix ranking method, the gravel-coir fibre-sand filter in 1:1:1 proportion separated by woven sisal hemp screen (P1M5S3) was emerged as the best filter combination, followed by gravel-sisal fibre-sand (1:1:1) with nonwoven sisal hemp screen and gravel-charcoalsand filter with metal screen.

Hydraulic performance of the best five filter combinations obtained by matrix ranking method is given in Fig. 8 . It can be inferred from the graph that the gravel-charcoalsand combination in 1:1:1 proportion separated by metal screens and gravel-coir fibre-sand (1:1:1) with woven sisal hemp fabric screen are the superior combinations. The latter combination was finally selected as the best multimedia filter combination considering its highest ranking in chemical removal efficiency and fairly better and consistent hydraulic efficiency especially at higher flow rates.

Sediment removal efficiency of the five superior filter combinations was studied (Fig. 9). The metal screen exhibited the least efficiency in removing sediments, while filters packed with coir fibre as one of the media showed low sediment concentration in outflow water even at high concentration in inflow. GFS filters with fibre screens showed better removal of sediments compared to the GCS filter with GI screen. Kambale et al. (2009) observed that the sediment concentration in the outflow increased with increase in sediment concentration of the recharging water for all treatments with varying depths of the filtration layers. Same trend was observed in this study also, and all
Fig. 8 Hydraulic performance of selected horizontal filters

Fig. 9 Sediment removal performance of selected filter combinations
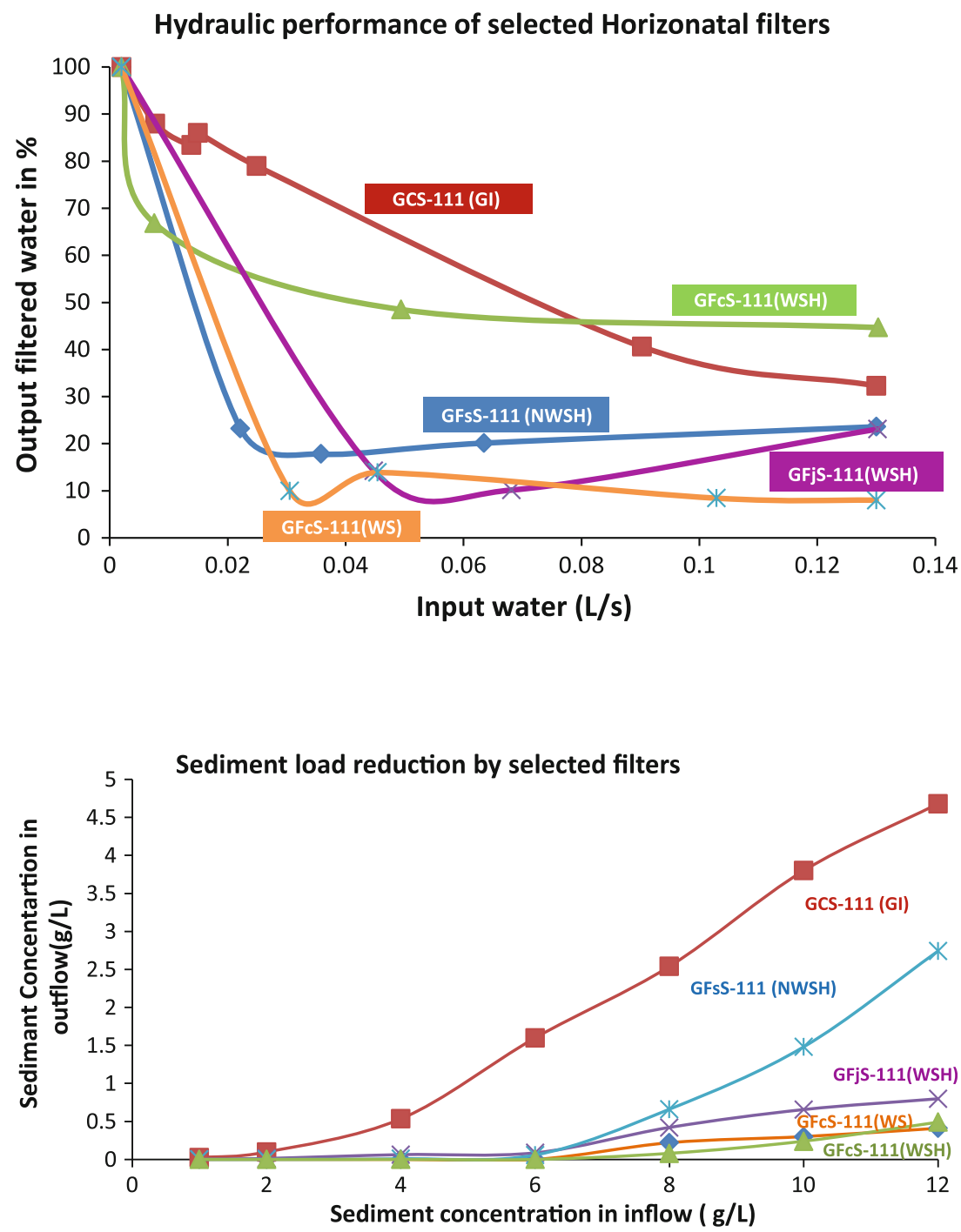
Fig. 10 Chemical removal efficiencies of selected filter combinations



of the GFS filters exhibited $100 \%$ per cent sediment removal at lower sediment concentration in inflow $\left(>6 \mathrm{~g} \mathrm{~L}^{-1}\right)$. For both the coir-fibre-filled GFS filters, the outflow sediment concentration was as low as $0.5 \mathrm{~g} \mathrm{~L}^{-1}$ even at fairly high inflow concentration of $12 \mathrm{~g} \mathrm{~L}^{-1}$ (95.8\% removal efficiency).

The chemical removal efficiencies of the top-listed five filter combinations were studied (Fig. 10). It was observed that the best combination selected by matrix ranking method, P1M5S3, performed consistent and better in removing the sediment load and chemicals in water.

The field evaluation of the best filter (P1M5S3) showed $97.24 \%$ efficiency in normalizing $\mathrm{pH}$ and $13.27 \%$ efficiency in reducing EC. The removal percentages of $\mathrm{Mg}$ and $\mathrm{Na}$ were 32 and $34 \%$, respectively, and were in good agreement with the laboratory results. But higher removal efficiencies were recorded for TS, $\mathrm{NO}_{3}{ }^{-}$and $\mathrm{SO}_{4}{ }^{2-}$ such as $89.7,66.36$ and $78 \%$, respectively. Similar to laboratory observations, $\mathrm{K}^{+}$concentration showed an increasing trend after filtration along with $\mathrm{Ca}^{2+}$, which could be attributed to the preferential leaching effects from bio-fibres having $\mathrm{K}^{+}$and $\mathrm{Ca}^{+}$in it. High concentration of $\mathrm{Ca}^{2+}$ observed in the outlet water from the field filter might also be due to the leaching out of $\mathrm{Ca}^{2+}$ salts into flowing water from the walls of the filter coated with white cement having high percentage of $\mathrm{CaCO}_{3}$.

\section{Conclusion}

Rain water harvesting with quantity enhancement and quality enrichment options assumes paramount importance in present-day scenario due to exponentially increasing demand and emphatically declining supply of usable water. Though rainwater is considered as a contamination-free source, human activities particularly in the industrial and agricultural sectors pollute this pure form of water. The recovery of relatively good quality rainwater for storage and reuse warrants the usage of a variety of filtering mechanisms in accordance with the need. The design and evaluation of appropriate, location-specific, biodegradable and cost-effective filter system is the need of the hour. In this context, a stormwater horizontal multimedia filter was developed and tested for its hydraulic efficiency and pollutant removal efficiency with various types of filter media, screens and media proportions.

The hydraulic study of filter media showed that gravel exibited highest efficiency of water conductance followed by coir fibre. But the hydraulic efficiency values of other fibres such as jute, sisal and oil palm were found to be inferior to those of sand, especially at lower filter volumes. Filter screens such as woven sisal, woven sisal jute, woven sisal hemp and metal screen showed better hydraulic conductivity compared to various nonwoven screens. A new terminology, UPI, has been introduced. It is the weighted average of the hydraulic efficiency and quality-improving efficiencies, giving extra weightage to the latter. For gravel-fibre-sand (GFS) filters, the proportion P1 (1:1:1), media M1 (charcoal) and screen S9 (no screen) had emerged as the highest performers with highest mean value of hydraulic efficiency. Universal Performance Indices of all the GFS filter combinations were computed for comparative studies, and the statistical analysis showed the media jute (M3), nonwoven sisal (S4) screen and media proportion 1:1:1 ( $\mathrm{P} 1)$ as the best. The analysis of variance at 0.01 significance level showed that all factors and their two-way and three-way interactions were highly significant. The superior 45 filter combinations that exhibited significantly higher performance based on its UPI values were delineated for detailed chemical analyses of water parameters. The average removal efficiency of eight chemical parameters and TS for the 45 filter combinations 
tested was $30.81 \%$. Based on the matrix ranking method, the gravel-coir fibre-sand filter in 1:1:1 proportion separated by woven sisal hemp screen (P1M5S3) had emerged as the best filter combination. The field evaluation of the filter showed $97.24 \%$ efficiency in normalizing $\mathrm{pH}$ and $13.27 \%$ efficiency in reducing EC. The removal percentages of $\mathrm{Mg}$ and $\mathrm{Na}$ were in good agreement with the laboratory results. High removal efficiencies were recorded for TS, $\mathrm{NO}_{3}{ }^{-}$and $\mathrm{SO}_{4}{ }^{2-}$.

The multi-media stromwater filter system (sand, gravel and fibre) separated by fabric screens is excellent in removing sediments, and fair in reducing sulphate, nitrate, magnesium and sodium concentrations. However, it performs comparatively poor in removing chloride and calcium and reducing the total hardness and alkalinity. The hydraulic efficiency of the filter mechanism is reasonably good, and it shows decreasing trend with increase in flow rate. The natural fibre filter media and screens used in this study are cheap, environmentally compatible and biodegradable, with usage of raw materials that are commonly available and renewable in nature. Future work must look into multimedia filters using bio-fibre media, and screens that could be directly attached along the stormwater flow path to make the rainwater treatment operations more costand energy-efficient.

Acknowledgments The authors are thankful to Dr. S.V. Ngachan, Director, ICAR Research Complex for NEH Region, Barapani, Meghalaya, India, and Dr. George V. Thomas, Director, Central Plantation Crops Research Institute, Kasaragod, Kerala, India, for their support and encouragements.

\section{Appendix}

Design of multimedia filter

A catchment area of 1 ha $\left(10,000 \mathrm{~m}^{2}\right)$ was considered. The average rainfall intensity of the study area as per the analysis of rainfall for 25-year design period (1985-2009) was $23.5 \mathrm{~mm} \mathrm{day}^{-1}$.

Hence, runoff volume diverted to the filter facility:

$\mathrm{WQ}_{\mathrm{V}}=$ drainage area in $\mathrm{m}^{2}(A) *$ runoff coefficient $\left(R_{\mathrm{V}}\right)$ $*$ av. rainfall intensity $(\mathrm{m})$

(Claytor and Schueler 1996; Urbonas 1999).

The runoff coefficient $R_{\mathrm{V}}$ was estimated using the formula:

$R_{\mathrm{V}}=0.05+0.009 *(I)$

where $I=$ percentage of watershed that is impervious.
It is approximated that $10 \%$ of the watershed area is impervious, and therefore, $R_{\mathrm{V}}=0.14$ and hence

$\mathrm{WQ}_{\mathrm{V}}=10,000 * 0.14 * 0.0235=32.9 \mathrm{~m}^{3} \approx 33 \mathrm{~m}^{3}$.

Surface area of filter $\left(A_{f}\right)$

$A_{\mathrm{f}}=\left(\mathrm{WQ}_{\mathrm{V}}\right)\left(d_{\mathrm{f}}\right) /\left[\left(K_{\mathrm{f}}\right)\left(h_{\mathrm{f}}+d_{\mathrm{f}}\right)\left(t_{\mathrm{f}}\right)\right]$

(Claytor and Schueler 1996; Urbonas 1999) where $\mathrm{WQv}=$ water quality volume diverted to the filter facility $\left(\mathrm{m}^{3}\right) ; A_{\mathrm{f}}=$ surface area of filter bed $\left(\mathrm{m}^{2}\right) ; d_{\mathrm{f}}=$ filter bed depth $(\mathrm{m}) ; k_{\mathrm{f}}=$ coefficient of permeability of filter media $\left(\mathrm{m}\right.$ day $\left.^{-1}\right) ; h_{\mathrm{f}}=$ average height of water above filter bed $(\mathrm{m}) ; t_{\mathrm{f}}=$ design filter bed drain time (days).

Therefore,

$A_{\mathrm{f}}=33 * 0.6 /\left\{\left(k_{\mathrm{f}}\right)(0.60+0.30)\left(t_{\mathrm{f}}\right)\right\}$.

Calculation of $k_{\mathrm{f}}$ : As per Todd (1976), the hydraulic conductivity of an entire system for stratified layers across the direction of flow was as follows:

$K_{\mathrm{f}}=\frac{z_{1}+z_{2}+z_{3}+\cdots+z_{n}}{\frac{z_{1}}{k_{1}}+\frac{z_{2}}{k_{2}}+\frac{z_{3}}{k_{3}}+\cdots+\frac{z_{n}}{k_{n}}}$

where $k_{1}=$ hydraulic conductivity of sand $=0.0001$ $\mathrm{m} \mathrm{s}^{-1}$ (Bratieres et al. 2010; CRCCH 2009); $k_{2}=$ hydraulic conductivity of gravel $=0.01 \mathrm{~m} \mathrm{~s}^{-1}(\mathrm{CRCCH}$ 2009); $k_{3}=$ hydraulic conductivity of fibre $=0.02 \mathrm{~m} \mathrm{~s}^{-1}$ (http://www.agagroup.co.uk/bioengineering/aga-advance; http://www.naturalworld.in); $k_{4}=$ hydraulic conductivity of fabric $=0.0022$ (Scott 2004; UNHSC 2009).

Consider a filter with three columns each having an identical width of $1 \mathrm{~m}$ and volume $1 \mathrm{~m}^{3}$. Let each layer be separated by woven/nonwoven fabric of $0.0045 \mathrm{~m}$ thickness. Then the total thickness of two fabric layers would be $0.009 \mathrm{~m}$, and hence, the effective width of each filter layer would be $0.997 \mathrm{~m}$.

Therefore,

$$
\begin{aligned}
K_{\mathrm{f}}= & (0.997+0.997+0.997+0.009) /(0.997 / 0.0001) \\
& +(0.997 / 0.01)+(0.997 / 0.02)+\left(0.009 / 2.2 \times 10^{-3}\right) \\
= & 3 /(9,970+99.7+49.85+4.09) \\
= & 3 / 10,123.64=0.000296 \mathrm{~m} \mathrm{~s}^{-1} .
\end{aligned}
$$

Hence, $A_{\mathrm{f}}=33 * 0.6 /\{(0.000296 * 3600 * 24)(0.9)(24 / 24)=$ $19.8 / 23.017=0.86 \mathrm{~m}^{2}$, say $0.9 \mathrm{~m}^{2}$.

Hence, the final specifications of the stormwater filter are fixed as follows:

Length $=1.5 \mathrm{~m}$

Width $=0.6 \mathrm{~m}$

Depth $=0.9 \mathrm{~m}$. 


\section{Size sedimentation chamber}

$A_{\mathrm{s}}=(0.049)\left(\mathrm{WQ}_{\mathrm{v}}\right) \mathrm{m}^{2}$ for impervious area $<75 \%$

$$
=0.049 * 33 \mathrm{~m}^{2}=1.62 \mathrm{~m}^{2}
$$

(Claytor and Schueler 1996; Urbonas 1999).

\section{Hydraulic loading rate}

Hydraulic loading rate $=$ flow rate $/$ surface area

i.e. $=[(33 * 1,000) /(24 * 3,600)] \mathrm{L} \mathrm{s}^{-1} /$

$0.9 \mathrm{~m}^{2}=0.424 \mathrm{~L} \mathrm{~s}^{-1} \mathrm{~m}^{-2}$.

\section{References}

Ahn HW, Park NS, Kim S, Park SY, Wang CK (2007) Modeling of particle removal in the first coarse media of direct horizontalflow roughing filtration. Environ Technol 28:339-353

Bahgat M, Dewedar MA, Zayed A (1999) Sand-filters used for wastewater treatment: buildup and distribution of microorganisms. Water Resour 33(8):1949-1955

Bergado DT, Manivannan R, Balasubramaniam AS (1996) Filtration criteria for prefabricated vertical drain geotextile filter jackets in soft Bangkok clay. Geosynth Int 3(1):68-79

Bratieres K, Fletcher T, Deletic A, Somes N, Woodcock T (2010) Hydraulic and pollutant treatment performance of sand based biofilters. In: NOVATECH-2010, Lyon, France 28 June-1 July

Chang NB, Islam MK, Wanielista MP (2012) Floating wetland mesocosm assessment of nutrient removal to reduce ecotoxicity in stormwater ponds. Int J Environ Sci Technol 9(3):453-482

Claytor RA, Schueler TR (1996) Design of stormwater filtering systems. Chesapeake Research Consortium Inc., USA

Cooperative Research Centre for Catchment Hydrology $(\mathrm{CRCCH})$ (2009) MUSIC-E-water user manual. CRCCH, University of Canberra, Canberra

Davis AP (2005) Green engineering principles promote low impact development. Environ Sci Technol 39(16):338A-344A

Egan T, Burroughs S, Attaway T (1995) Packed bed filter. In: Fourth biennial stormwater research conference, Florida, USA

Fletcher T, Duncan H, Poelsma P, Lloyd S (2004) Stormwater flow and quality, and the effectiveness of non-proprietary stormwater treatment measures-a review and gap analysis. Cooperative Research Centre for Catchment Hydrology, Monash University, Australlia

Gironas J, Adriasola JM, Fernandez B (2008) Experimental analysis and modeling of a stormwater perlite filter. Water Environ Res 80(6):524-539

Hamoda MF, Al-Ghusain I, Al-Jasem DM (2004) Application of granular media filtration in wastewater reclamation and reuse. J Environ Sci Health A Tox Hazard Subst Environ Eng 39(2):385-395

Hatt BE, Fletcher TD, Walsh CJ, Taylor SL (2004) The influence of urban density and drainage infrastructure on the concentrations and loads of pollutants in small streams. Environ Manage 34(1):112-124

Hatt BE, Siriwardene N, Deletic A, Fletcher TD (2006) Filter media for stormwater treatment and recycling: the influence of hydraulic properties of flow on pollutant removal. Water Sci Technol 54(6-7):263-271

Hatt BE, Fletcher TD, Deletic A (2008) Hydraulic and pollutant removal performance of fine media stormwater filtration systems. Environ Sci Technol 42:2535-2541
Hatt BE, Fletcher TD, Deletic A (2009) Hydrologic and pollutant removal performance of stormwater biofiltration systems at the field scale. J Hydrol 365:310-321

Hipp JA, Ogunseitan O, Lejano R, Smith CS (2006) Optimization of stormwater filtration at the urban/watershed interface. Environ Sci Technol 40(15):4794-4801

Hsieh C-H, Davis AP (2005) Evaluation and optimization of bioretention media for treatment of urban stormwater runoff. J Environ Eng (ASCE) 131(11):1521-1531

Indian Standard Code: IS 3025:1987

Johir MAH, Lee JJ, Vigneswaran S, Kandasamy J, Shaw K (2009) Treatment of stormwater using fibre filter media. Water Air Soil Pollut Focus 9:439-447

Kambale JB, Sarangi A, Singh DK, Singh AK (2009) Performance evaluation of filtration unit of groundwater recharge shaft: laboratory study. Curr Sci 96(4):471-474

Karunakaran K, Thamilarasu P, Sharmila R (2009) Statistical study on physicochemical characteristics of groundwater in and around Namakkal, Tamilnadu, India. E-J Chem 6:909-914

Kim R-H, Lee S, Jeong J, Lee J-H, Kim Y-K (2006a) Reuse of greywater and rainwater using fiber filter media and metal membrane. Desalination 202:326-332

Kim R-H, Lee S, Jeong J, Gee CS (2006b) Development of fibre filter media to control heavy metals and nutrients in urban stormwater runoff. Mater Sci Forum 510-511(2006):918-921

Lonigro A, Pollice A, Spinelli R, Berrilli F, Di Cave D, D'Orazi C, Cavallo P, Brandonisio O (2006) Giardia cysts and Cryptosporidium oocysts in membrane-filtered municipal wastewater used for irrigation. Appl Environ Microbiol 72(12):79167918

Martinson DB, Thomas T (2003) Improving water quality by design. In: 11th International rainwater catchment systems conference, Texcoco, Mexico, August, 2003

Melbourne Water (2005) WSUD engineering procedures: stormwater. CSIRO Publishing, Melbourne

Min SH, Eberhardt TL, Jang M (2007) Base-treated juniper fiber media for removing heavy metals in stormwater runoff. Pol J Environ Stud 16(5):731-738

Naz H, Ashraf S, Naz A (2009) Bacteriological and physio-chemical assessment of drinking water quality of different areas in Aligarh. Pollut Res 28(4):685-690

Paul MJ, Meyer JL (2001) Streams in the urban landscape. Annu Rev Ecol Syst 32:33-365

Praveen A, Sreelakshmy PB, Gopan M (2008) Coir geotextile-packed conduits for the removal of biodegradable matter from wastewater. Curr Sci 95(5):655-658

Samuel MP, Satapathy KK (2008) Concerted rainwater harvesting technologies suitable for hilly agro-ecosystems of Northeast India. Curr Sci 95(9):1130-1132

Scott DJ (2004) Geotextiles for filtering water and oil fluids. In: Proceedings of North American Geosynthetics Society, Las Vegas, USA

Sinha DK, Rastogi GK, Kumar R, Kumar N (2009) Correlation study among water quality parameters - an approach to water quality management. J Environ Sci Eng 51:111-114

Thomas PR, Grenne GR (1993) Rainwater quality from different roof catchments. Water Sci Technol 28:290-299

Todd DK (1976) Groundwater hydrology. Wiley, New York

University of New Hampshire Stormwater Center (UNHSC) (2009) UNHSC design specifications for porous asphalt pavement and infiltration beds. New Gregg Hall, Hampshire

Urbonas BR (1999) Design of a sand filter for water quality enhancement. Water Environ Res 71(1):102-113

Wanielista M, Chang N-B (2008) Alternative stormwater sorption media for the control of nutrients. Stormwater Management Academy, University of Central Florida, Orlando 
Wildeman TR, Gusek JJ, Miller A, Fricke J (1997) Metals, sulfur, and carbon balance in a pilot reactor treating lead in water. In: Alleman BC, Leeson A (eds) In situ and on-site bioremediation, vol 3. Battelle Press Columbus, OH, pp 401-406

Wong THF, Fletcher TD, Duncan HP, Jenkins GA (2006) Modelling urban stormwater treatment-a unified approach. Ecol Eng 27(1):58-63
Yuzwa G, Eng P (1982) Alkalinity reduction by chloride form anion exchangers. Water Treatment Coordinators' Meeting, Alberta Government Services, April 1982 